\title{
豊田高専における技術士第一次試験合格 に向けた継続的な学生指導について
}

\author{
Continual Improvement of Leading Procedure for Passing of First-Step Professional
} Engineer Examination in Toyota National College of Technology

\author{
小林 睦*1 \\ Makoto KOBAYASHI
}

\section{1.はじめに}

建設業界においては，業務の遂行上技術士資格の必 要性を問われることが多い。したがって，これを反映 してか建設関連部門での受験者は多く，平成20年度の 技術士第一次試験受験者のうち建設, 環境, 衛生工学, 上下水道工学部門の受験者が占める割合は 7 割程度で ある1).

豊田工業高等専門学校環境都市工学科においては, 平成16年度に環境都市工学プログラムが建設部門での JABEE認定を受けている。 今日までに本プログラムを 修了した37名の修了生は建設部門での技術士補登録が 可能であり，所定の実務経験を経ると技術士第二次試 験を受験することができる.ところが, 同期間において, 高専本科 5 年卒業と同時に社会で活躍している技術者 は170名程度にのぼり, 彼らはJABEE修了生でないた めに，それぞれの業務に従事しながら試験勉強，受験 を行い，第一次試験に合格しなければ，第二次試験の 受験資格を得られない。このような環境では, 専門知 識はレベルアップがなされる一方で, 大学卒業程度の 学力レベルを問う理数系の共通科目については, 実務 に携わる時間が長くなればなるほど知識レベルは低下 していくことが考えられる.このことから, 在学中に 受験して合格することが最も望ましいと考えられる.

そこで筆者らは, 高専のキャリア支援の一環として, 平成17年度より希望学生を対象とした技術士第一次試 験合格に関する補講を実施してきた，本論文では，年 度毎の学生指導方法に関して, 学生の受験状況や合格 率・得点状況を精查しながら継続的に改善を行い, 最 適な指導方法の提案について述べていく.

\section{2. 技術士第一次試験に対する補講計画}

2.1 豊田高専のカリキュラムと技術士第一次試験 専門科目分野の対応

豊田高専環境都市工学科においては, 一般的な土木

平成 22 年 5 月 31 日受付

※ 1 豊田工業高等専門学校

\section{松 本 嘉 孝*1 \\ Yoshitaka MATSUMOTO}

系の教育機関と同様の土木主要分野に加えて, 環境系 の科目を付加してカリキュラムを構成している．表 1 に建設部門に扔ける技術士第一次試験の専門科目に課 せられる分野と本校の開講科目・学年との関連を示す. 専門科目は35問のうち25問を選択して回答する. 各分 野からの出題数は平均的であるので, 建設部門におい ては, 1 分野につき 3 問程度が出題されている.

先ず，表 1 より，建設部門に関して，本校のカリ キュラムと出題分野を比較すると, 電力土木, 鉄道抒 よびトンネル分野に関して, 対応する授業科目がない ことが指摘できる。一方, 本校においては, 基礎理論 の徹底と実験実習の充実を教育目標に掲げていること から，土質及び基礎，鋼構造及びコンクリートについ ては対応科目が多く, 出題分野に対して偏りがあるこ とも指摘できる. 特に, ※印を付した科目は, 第 4 学 年以降の開講科目の大学単位化の導入に伴い, 統廃合・ 変更される科目である.

環境部門について, 同様の出題分野と本校での開講 科目の対応表を表 2 に示す。ここで, 括弧内の科目は 平成 18 年度入学生, すなわち平成 21 年度の第 4 学年か ら開講される科目であり，5年生以上については，対 応科目はないことになる。したがって，6分野のうち 3 分野に関しては, 本校の学生は学習できていない. 一方で, 大気, 水, 土壤等の環境の保全, 環境の状況 の測定分析及び監視, 自然生態系及び風景の保全の 3 分野については, 土木主要分野と同様に 3 科目程度が 対応しており，環境部門についても技術士第一次試験 の出題分野に対して本校の開講科目は偏りがあること が指摘できる.

\section{2 技術士第一次試験に対する補講の位置付け}

前節のように, 本学科のカリキュラムを考慮すると, 学生が在学中に技術士第一次試験を受験して正答にた どりつくまでには学習できていない分野に関する補講 等の指導が必要になってくる. すなわち, 補講の存在 を知らないか，あるいはこれを受講する意志を持たな いと, 合格への道筋が見えないために在学中の受験を 断念してしまう可能性がある. したがって, 受験の動 
表 1 技術士第一次試験専門科目分野と豊田高専環境都市工学科開講科目との対応（建設部門）

\begin{tabular}{|c|c|c|c|}
\hline 野 & 関連科目 & $\begin{array}{l}\text { 開講学年 } \\
\text { (年) }\end{array}$ & 平成18年度以降の変更等 \\
\hline \multirow{4}{*}{ 土質及び基礎 } & 土質力学 I & 3 & \multirow{4}{*}{$\begin{array}{l}\text { 平成18年度入学生より, 地盤工学と防災工学は地盤 } \\
\text { 防災工学に統合. }\end{array}$} \\
\hline & 土質力学 II & 4 & \\
\hline & 地盤工学* & 5 & \\
\hline & 防災工学* & 5 & \\
\hline \multirow{6}{*}{ 鋼構造及びコンクリート } & 建設材料学 & 2 & \multirow{6}{*}{$\begin{array}{l}\text { 平成18年度入学生より, 構造設計は } 4 \text { 年生開講の構 } \\
\text { 造解析へ変更. }\end{array}$} \\
\hline & 構造力学 I & 3 & \\
\hline & 構造力学 II & 3 & \\
\hline & コンクリート構造学 I & 3 & \\
\hline & コンクリート構造学 II & 4 & \\
\hline & 構造設計※ & 5 & \\
\hline \multirow{2}{*}{ 都市及び地方計画 } & 都市計画 & 5 & \multirow{2}{*}{ 平成18年度入学生より, 交通計画は閉講. } \\
\hline & 交通計画※ & 5 & \\
\hline \multirow{3}{*}{ 河川, 砂防及び海岸・海岸 } & 水理学 I & 3 & \multirow{3}{*}{$\begin{array}{l}\text { 砂防については, 防災工学も関与. } \\
\text { 海岸については該当無. }\end{array}$} \\
\hline & 水理学 II & 4 & \\
\hline & 河川・港湾工学 & 4 & \\
\hline 港湾及び空港 & 河川・港湾工学 & 4 & 空港については該当無. \\
\hline 電力土木 & - & - & - \\
\hline \multirow{2}{*}{ 道路 } & 交通工学 & 4 & \multirow{2}{*}{ 平成18年度入学生より, 交通工学は 3 年次開講. } \\
\hline & 道路工学 & 4 & \\
\hline 鉄道 & - & - & - \\
\hline トンネル & - & - & - \\
\hline 施工計画, 施工設備及び積算 & 建設管理計画 & 5 & - \\
\hline \multirow{2}{*}{ 建設環境 } & 環境アセスメント* & 4 & \multirow{2}{*}{$\begin{array}{l}\text { 平成 } 20 \text { 年度入学生より, 環境アセスメントは閉講. } \\
\text { 平成 } 18 \text { 年度入学生より, 水環境工学は環境水質学に } \\
\text { 名称変更. }\end{array}$} \\
\hline & 水環境工学 & 4 & \\
\hline
\end{tabular}

表 2 技術士第一次試験専門科目分野と豊田高専環境都市工学科開講科目との対応（環境部門）

\begin{tabular}{|c|c|c|c|}
\hline 分 & 関連科目 & $\begin{array}{c}\text { 開講学年 } \\
\text { (年) }\end{array}$ & 平成18年度以降の変更等 \\
\hline \multirow{4}{*}{$\begin{array}{l}\text { 大気, 水, 土塤等の環境の保 } \\
\text { 全 }\end{array}$} & 大気環境 & 2 & \multirow{4}{*}{$\begin{array}{l}\text { 平成 } 18 \text { 年度入学生より, 水環境工学は環境水質学に } \\
\text { 名称変更, 大気環境は } 3 \text { 年次開講. }\end{array}$} \\
\hline & 土鎄環境 & 3 & \\
\hline & 水環境工学 & 4 & \\
\hline & 上下水道工学 & 4 & \\
\hline 地球環境の保全 & (地球環境概論) & $(2)$ & 平成 18 年度入学生より, 地球環境概論が 2 年次開講. \\
\hline 廃棄物等の物質循環の管理 & - & - & - \\
\hline \multirow{3}{*}{$\begin{array}{l}\text { 環境の状況の測定分析及び } \\
\text { 監視 }\end{array}$} & 水環境工学 & 4 & \\
\hline & 環境計測実験 & 4 & \\
\hline & リモートセンシング & 5 & \\
\hline \multirow{4}{*}{ 自然生態系及び風景の保全 } & 環境植生学 & 5 & \multirow{4}{*}{$\begin{array}{l}\text { 平成 } 18 \text { 年度入学生より景観デザインは閉講. 平成 } 20 \\
\text { 年度入学生より, 環境アセスメントが閉講, 環境生 } \\
\text { 物学が } 2 \text { 年次開講. }\end{array}$} \\
\hline & 景観デザイン* & 5 & \\
\hline & 環境アセスメント & 4 & \\
\hline & (環境生物学) & 2 & \\
\hline $\begin{array}{l}\text { 自然環境の再生・修復及び自 } \\
\text { 然とのふれあい推進 }\end{array}$ & （水域環境） & (5) & 平成18年度入学生より水域環境が 5 年次開講. \\
\hline
\end{tabular}

機付けのために，申し込み時点（6月）に技術士資格 と受験内容についてのガイダンスを行い, 一連の活動 の周知を図った.

ところで, 高専本科においては, 第 4 学年の夏季休 業中に 2 週間の校外実習があるために，実習の日程に よっては夏休みの補講に出席できない。また, 全国高
等専門学校体育大会の東海地区大会が 7 月中旬に, 全 国大会が 8 月下旬に実施されることも補講への出席に 影響を及ぼす要因である。 そこで，通常の座学の授業 のような補講だけでは学生の知識レベルの向上に繋が らないと考えられ, 課題を課したり, 模擬問題の配布 も併せて行ってきた。 


\section{3. 技術士第一次試験に対する指導内容 \\ 3. 1 補講内容}

技術士第一次試験は多肢選択問題であるために，消 去法によって正答にたどりつく手法も有効であると考 えられる，そこで，より多くの情報を提供して，浅く ても幅広い知識を身につけさせることに主眼を置い た．したがって，通常の授業のような板書ではなく， パワーポイントによるスライド形式で行い, 視覚的に 理解させる工夫をした。

建設部門での補講内容は，実務レベルの話をメイン にして，鉄道，トンネル，電力土木に加えて国土交通 白書の紹介を行っている。国土交通白書の内容は，例 えば道路や鉄道，都市計画の分野に関連する項目もあ り，幅広い情報を提供するためには有意義であると考 えた，さらに，建設業界の最近の動向について，担当 教員が現場での経験を活かして説明を加えることで, 学習意欲の確保に繋げる工夫を行ってきた.

環境部門での補講においても，環境白書を用いてい ることと, 土木工学系の学科ではなされない分野につ いて担当教員の技術経験や知識を活かした講義を行っ ている。 また，法律や規制といった学生になじみのな い分野を体系的にまとめることで学生の理解を促し た.

またこれらのスライドは資料として学生に配布す るとともに, 市販の問題集から過去問題を抜粋して模 擬試験を作成したり, 解説の部分を課題として配布し て, 学習材料の提供を行った.

\section{2 指導内容}

表 3 に平成17年度より行っている技術士第一次試験 に対する補講計画を示す，初年度は，基礎科目につい て前年度の試験問題の解説を行い，この科目の特徵を 概観させた。それ以降は，主に建設・環境部門の専門 科目について実施している.

\section{4. 指導内容の改善}

\section{1 平成17年度}

初年度である平成 17 年度は, 10 月の試験前 1 週間に 専門科目の補講を 4 回実施した。ただし，前年度の試

表 3 技術士第一次試験合格のための指導内容

\begin{tabular}{|c|c|}
\hline 年 度 & 指 導 内 容 \\
\hline 平成17年度 & 補講：4 回程度（試験前 1 週間より開始） \\
\hline \multirow{3}{*}{ 平成18年度 } & 補講：4 回程度（7 月より開始） \\
\hline & 過去問題配布，模擬試験 \\
\hline & 一日一問メール \\
\hline \multirow{3}{*}{ 平成19年度 } & 補講：4 回（6月より開始） \\
\hline & 過去問題配布, 模擬試験 \\
\hline & 課題提出 \\
\hline \multirow{3}{*}{ 平成20年度 } & 補講： 2 回 $(6,7$ 月に実施） \\
\hline & 過去問題配布，模擬試験 \\
\hline & 補講で使用したスライド資料の配布 \\
\hline
\end{tabular}

験問題の解説を含めたり, 基礎科目の概要を説明した ため, 1 回の補講で費やした時間は次年度以降の 2 倍 程度に及んだ。

平成17年度の活動から, 高等専門学校体育大会の東 海地区大会が 7 月に実施されるために学生生活はクラ ブ活動にバランスがシフトされることと, 前学期末試 験が技術士第一次試験の 2 週間前（9月末）に実施さ れることから，補講を実施する時期が試験直前になっ てしまったことから，受験日までの動機保持と継続的 に学習を促すことが課題として抽出された。

\section{2 平成18年度}

平成18年度は, 恒常的に技術士第一次試験を意識さ せるために，学生の携帯電話アドレス宛に「一日一問 メール」を送付した。これは，専門分野の基礎知識を 強化することを目的として, 文章の正誤を問う主旨の メールを配信するものである，翌日には，その問題に 関する解説を配信する。このことに加えて, 前年度同 様に夏休みに補講を実施し, 過去問題の配布を行った が, 校外実習やクラブ活動のために, 出席状況は 3 割 程度（全47名）であった。

平成18年度の活動において，一日一問メールの回答 率は良かったが，携帯メールの文字制限を考慮すると 情報量が少なくなってくることと, 教員がメールを送 受信できる環境にいることが情報発信の条件になるこ とから，多くの情報を提供できるものとはいえなかっ た。しかしながら, 情報受信のたびに試験の存在を認 識していたことが考えられ, 動機を保持させる材料に なったものと推察される。一方で, この年度より, 第 4 学年の受験希望者が増えたが, 校外実習のために補 講に参加できなかったことから, どの学年においても 継続的に学習できる環境づくりが次年度の問題として 挙げられた.

\section{3 平成19年度}

平成19年度は，知識向上と動機確保の両者を満たす ために, 申し込み時点より, 補講および模擬試験の実 施, 課題として問題集を配布して後日ノートを提出さ せることとした，夏休み中においても模擬試験を実施 し, 資格取得意欲の維持に努めた. 一方で, 課題の提 出状況については, 提出する学生は限定されていたも のの, 受験希望者の多くが定期的に課題を持ち帰って いたことを確認している.

補講への出席状況は, 例年より早い段階で実施した 平成19年度においても変化はなく, 特に, 当年度より 数名の 3 年生が受験を希望したが, 彼らにとって補講 は従来の補講という位置付けにはなく, 4,5 年生を 対象に作成したスライドでは理解を助ける材料にはな らなかった。

\section{3.1 補講・課題が得点に及ぼす影響}

この年度まで実施してきた補講や課題配布等の一連 の指導内容が得点に及ぼす影響を調べた。 


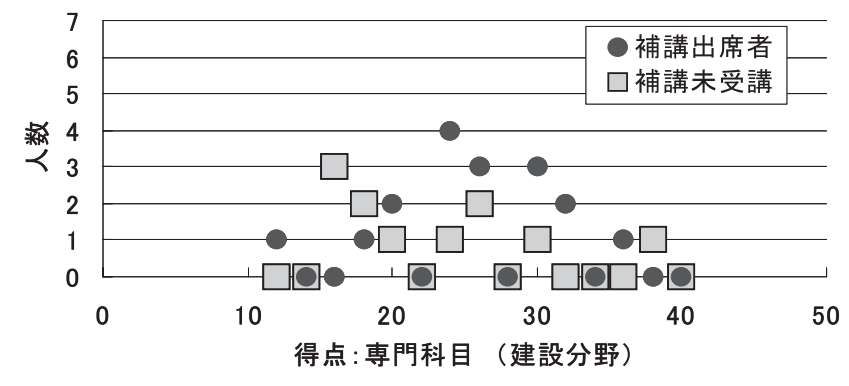

図 1 補講の出欠状況と得点分布の関係（建設部門）

技術士第一次試験においては，専門科目に加えて， 技術士としての適性を問う適性科目，工学の基礎知識 を問う基礎科目, 大学卒業程度の理数系科目のレベル を問う共通科目 (数学, 物理学, 生物学, 化学, 地学 から 2 科目選択）の計 4 科目について試験を受けなけ ればならない。試験の結果より，適性科目および基礎 科目については，ほぼ全員の学生が合格基準を満足さ せていた，以下には，専門科目の得点率に補講・課題 が及ぼす影響について考察していく。

(1) 建設部門

図 1 に平成19年度における受験者の得点分布と補講 の出欠状況の関係を示す。ここで, 補講出席者は前年 度までに一度でも補講に出席した学生としている.ま た, 専門科目の満点は50点である。これより, 補講出 席者の得点分布のピークが高得点側に推移しているこ とから, 補講を受けた学生の得点率が向上しているこ とが窅える。ここで, 補講を受けようとする学生はそ もそも向上心がある者が多いことから, 補講の効果を 検証することは難しい．しかしながら，彼らが，専門 科目に㧍ける理論だけでなく実務レベルの話に関する 情報を得ると，正答率は向上してくると考えられる. また，受験申し込みから試験日までの 4 ケ月間に学習 意欲を維持させるための課題については, 自らで学習 できる環境づくりの一助になったものと考えられる.

(2) 環境部門

平成19年度における補講の出欠状況と得点分布の関 係を図 2 に示す。これより，科目の合格基準（20点） を満たした補講出席者数は若干多いことが指摘でき る。しかしながら, 全体的には補講出席により得点率 が向上したとはいい難い。これは，正規のカリキュラ ムでは受験分野を網羅していないことに起因するもの であり，僅かな時間の補講ではそれを補うことができ なかったことが得点率の向上に直結しなかった原因で あると考えられる。

\section{3.2 持続可能な指導方法の模索}

前項のように, 知識レベルを向上させるための補講 は重要な位置付けにあると考えられる一方で，この種 のキャリア支援を継続的に続けていくためには，教員 側の補講を実施する労力および学生側の受講する際の 時間的拘束に対する効果を期待するよりも，学生自身

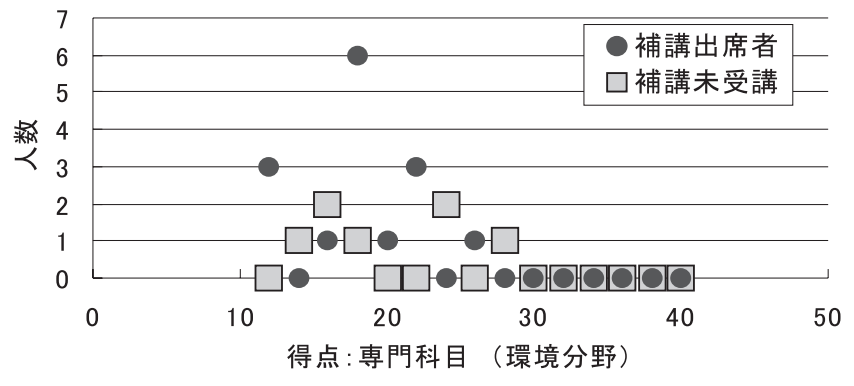

図 2 補講の出欠状況と得点分布の関係（環境部門）

が継続的に学習する環境づくりを行うことが重要であ ると考えられた。 そこで, 補講を実施するにあたって 視覚的に理解を助けるために作成したスライド資料の 配布を行うことで，これを補講に代えていくことを検 討する必要があると考えられた。

さらに, 資料配布に加えて問題集の貸し出しも行い, 多くの学習教材を提供することで, 能動的に試験に臨 もうとする学生をサポートしつつ, 全体を通して受動 的な学習体制からの自立を促すような工夫も必要であ ろう.

\section{4 平成20年度}

平成 20 年度は, 平成19年度までの補講出席者が少な かったことから, 受験希望者自身に自らの知識レベル を把握させることも目的として, 夏季休業前に 2 回の み補講を行った。 さらに, 資格取得意欲の維持のため に, 過去問題の配布と模擬試験を実施してきた。補講 回数を減らした分の情報量低下を相殺するために， ス ライド資料を印刷して学生に配布した.

この年度は, 第 3 学年に対しても技術士試験に関す るガイダンスを実施したところ, 受験希望者が 9 名に 増加し, 合計56名（内専攻科生 6 名）が試験に臨んだ。 課題配布や模擬試験の日程は教室に掲示し, 模擬試験 は自らで実施できるように問題を用意して教室を確保 した，平成17年度から受験希望者が増加したにもかか わらず, 補講や課題提供, 模擬試験を実施するための 教員の労力は軽減されてきた.

\section{5. 継続指導による受験者数, 合格者数の推移 \\ 5.1 受験者数の推移}

図 3 に, 平成17年度以降の技術士第一次試験受験者 全体及び部門別の推移を示す。これより, 年度の進行 に伴って部門ごとには増減が見られるが, 全体の受験 者は増加していることが指摘できる。これは，一連の キャリア支援活動が学生に周知されていったことによ るものと考えられる. 図 4 に本科生における学年別の 受験者数の推移を示す.これより, 各学年共に受験者 数は増加傾向にあることが確認でき, 特に第 4 学年の 受験者数が多いことが指摘できる。これは, ガイダン スだけでなく, 進路説明会や授業の中で建設業界にお いては，技術士資格が特に重要な位置付けにあること 


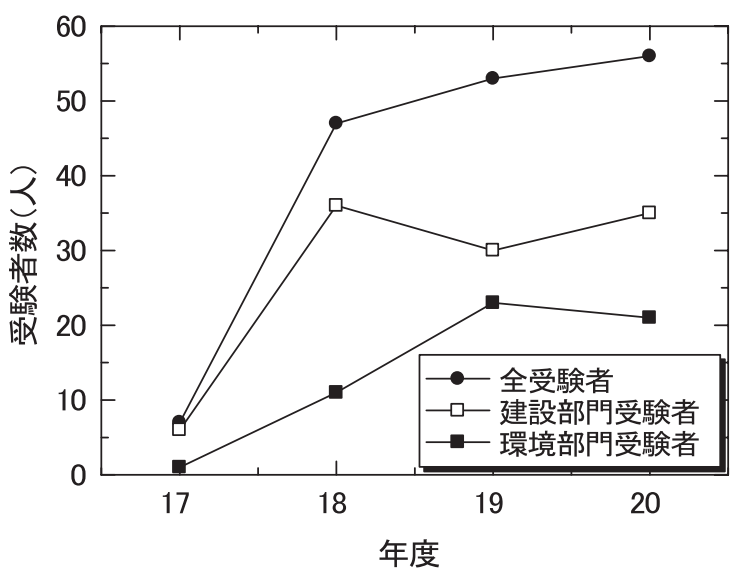

図 3 受験者数の推移（全体及び部門別）

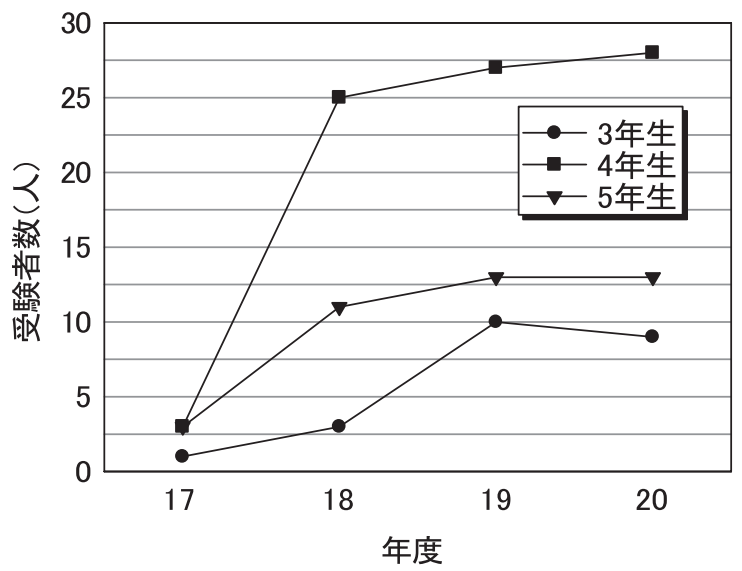

図 4 受験者数の推移（学年別）

を伝えていることに加えて，5年次の就職活動や編入 試験においても高評価を得られるであろうと考えたた めに, 積極的に試験に臨んでいったものと考えられる. また， 3 年生の受験者数が増加傾向にあるのは，資格 取得意欲を向上させることと試験に慣れるために受験 した方がよいとガイダンス時に勧めたことに起因する ものである。ただし，試験慣れや受験回数が得点率に 及ぼす影響については，客観的なデータがないために 検証できていない，検定料と効果のバランスを考える と, 次年度以降は模擬試験を正規の試験時間割と同じ ような時間配分で実施したり，校内でこれらの成果を 挙げていくように教育方法の改善が必要であろう。

図 5 には, 専攻科生を除く本科生の学年別の建設, 環境部門の受験者数の推移を示す。ここで, 専攻科生 を除いた理由は，豊田高専における専攻科過程を含め た 4 年間の環境都市工学プログラムがJABEE 認定を 受けており，学生は専攻科修了と同時に修習技術者に なれるために，総じて受験に対する意識が低い，さら に, 学生総数にばらつきがあり, 受験者数の絶対值で は傾向を把握できないためである。

図 5 より, 受験者数の多い第 4 学年において, 毎年 のように建設部門と環境部門のどちらを受験するかを 迷っていることが窥える．特に平成19年度において顕 著である。このことは, 申し込みが 6 月であるために，

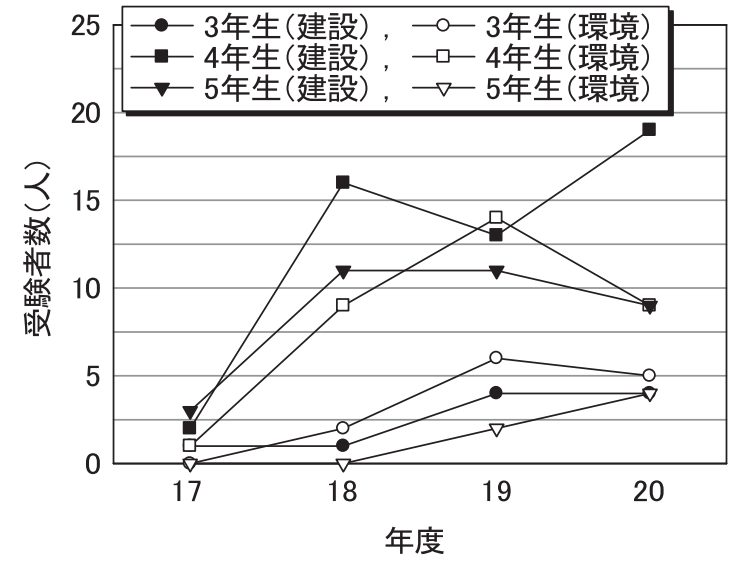

図 5 受験者数の推移 (学年・部門別)

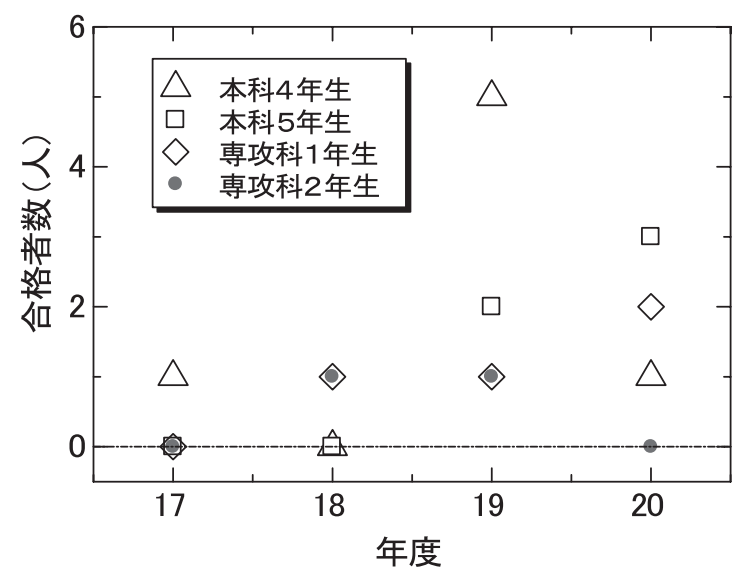

図 6 過去 4 年間における合格者の推移

3 年次に履修してきた土木主要科目への興味よりも, 環境部門であれば暗記で対応できると考えたものと推 察される。したがって, 翌年度以降は，ガイダンスの 中で部門選択についての注意事項としてこの問題を挙 げたところ，図からも確認できるように環境部門の受 験希望者が減り, 建設部門の受験希望者が増加した。

このように，平成 20 年度までの受験者数は増加傾向 にあり，ある程度の合格者を輩出していく一連の学生 指導は, 教員の負担を当初より軽減することも視野に 入れて改善を行っているので, 持続可能な発展である といえよう。

\section{2 合格者数の推移}

一連の活動の成果を確認するために, 図 6 に平成 17 年度から 4 年間における技術士第一次試験の合格者の 推移を示す。ここで, 合格者の内訳は, 平成 17 年度の 4 年生および平成 19 年度の専攻科 2 年生, 平成 20 年度 の 5 年生 2 名と専攻科 1 年生 2 名が環境部門の合格者 であり，それ以外は建設部門の合格者を示している. これより, 高専本科の学生の合格者数が専攻科生を上 回っていることが指摘できる. 専攻科生の受験意欲が 高くないことは，既に述べたとおりであるが，技術士 試験を受験しょうとする専攻科生の知識レベルは十分 に高いために, 受験者数に対する合格率は, 平成19年 度は 6 割強, 平成 20 年度は 4 割にも及んでいることは 
特記すべきである。これは，専門知識が高いレベルの 学年で受験を数回経験したり, 公務員試験のための学 習によって専門知識が向上したことが要因であると考 えられる。 また, 図 6 より, 高専本科の合格者数が増 加傾向にあることは, 一連の活動が学科全体に周知さ れてきたことに起因して, 資格取得意欲が高まり受験 者数が増加したことによるものであると考えられる. 一方で，資格取得に対する動機を長期間維持し続ける ためにも専門知識の多くを学んでいない第 3 学年に受 験を勧めてきたが，受験料に対する費用対効果を考え ると，今後は校内で対応していくことを検討していか なければならない。

\section{6.おわりに}

本報告では, 高等専門学校在学中に技術士第一次試 験に合格するための一連の学生指導を実施し, これを 検証しながら継続的に改善してきた，その結果次のよ うな結論を得た。

先ず，在学中に技術士第一次試験に合格するために は，正規のカリキュラム以外で専門分野の実務レベル の情報を収集し, 知識を習得していく必要がある。そ のためには，補講の実施が有用であると考えられる が, 学生の課外活動・生活状況を考慮すると課題や解 説付きの過去問題集, 写真・イラストを多用して教員 が独自に作成した資料の配布で対応することが重要で ある。 これを定期的に行うことで，必要な情報の提供 とともに試験に対する動機を高いレベルで維持するこ とが必要であることも分った。

また，高専本科在学中の合格を目指すには， 3 年生
からの受験により資格取得意欲を向上させることが望 ましいが，校内で実施する模擬試験を正規の試験同様 の時間配分にすることで, 検定料を無駄にすることな く試験にも慣れさせることができるものと考えられ る. このような教育方法は, その後の授業・実習等で 専門知識を習得していく姿勢を好転させていくきっか けにもなり得る。

さらに, 学科内で継続的な一連の活動が全体の受験 に対する気運を高めていくことが，この種の学生指導 の持続可能な発展に繋がるといえよう.

\section{参 考 文 献}

1 ）技術士会：平成20年度技術士第一次試験合格者 技術部門別試験結果, 2009

2 ）文部科学省: 報道発表, 平成 $20,19,18,17$ 年度技 術士第一次試験の結果について, 2008, 2007, 2006, 2005

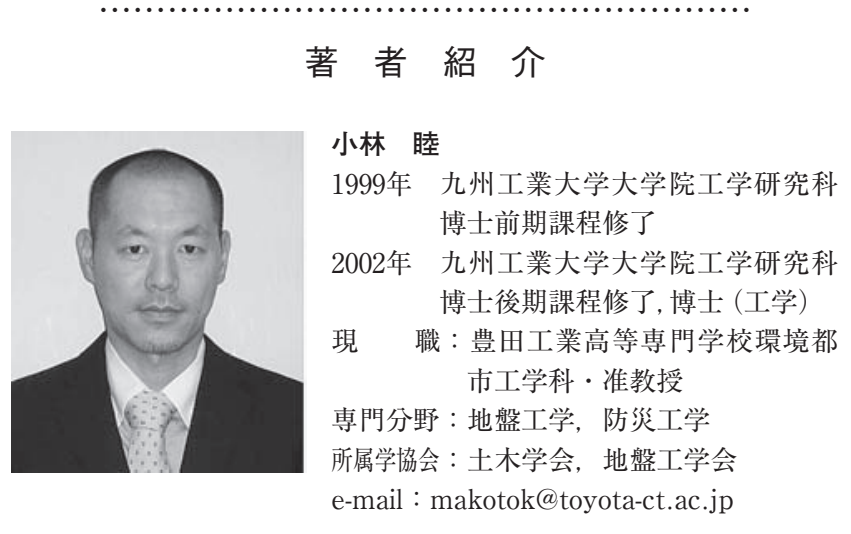

